\title{
Procedures and Processes Followed in the Appointment of Principals for School Leadership and Management
}

\author{
Sharon Thabo Mampane \\ University of Pretoria, Groenkloof Campus, Pretoia, Gauteng Province, South Africa, 0002 \\ Telephone: +27124202499, Fax: +27124203581, \\ E-mail: sharon.mampane@up.ac.za
}

KEYWORDS Appointment Criteria. Career Pathways. Level Hopping. Policy Implementation. Principalship

\begin{abstract}
The purpose of the qualitative descriptive study on which this paper is based was to explore the procedures and processes followed in appointing principals for school leadership and management in the Mpumalanga and Limpopo Provinces of South Africa. Using a qualitative, multiple case study approach, fifteen primary school principals were purposely sampled and interviewed by means of semi-structured interviews to explore issues of equity and fairness in principal appointments and pathways to becoming principals. The findings reveal a trend of level hopping and a flawed implementation of the stipulated appointment processes. There was also evidence of power-play among the different stakeholders and micro-politicking in the appointment procedures. Recommendations are that leadership and management skills training should be undertaken by teachers aspiring to be principals and that the criteria for principal appointments should be revised to include higher academic and professional qualifications. A further recommendation is the development of a monitoring tool to ensure quality in the appointment of principals.
\end{abstract}

\section{INTRODUCTION}

For decades principals have been recognised as important contributors to the effective functioning of schools because leadership is central to school achievement (The Wallace Foundation 2012). Schools need capable educational managers and, therefore, education reform policies should be formulated to address the appointment processes and procedures in schools. Education is finally embracing school leadership as an essential ingredient in reform which is worthy of investment in its own right. In facing the pressure for all children to achieve high standards, states and districts are, increasingly, recognising that successful school reform depends on principals being well prepared to make changes in schools and to improve instruction - not just manage buildings and budgets (Mitgang 2010: 18). The appointment procedures and processes, especially in South Africa, differ because of historical 'roots', geographical 'location' and 'cultural differences' (Johnson 2004: 119). These differences affect how school principals lead and manage schools as well as factors, such as their capacity, self-concept, ideas about attitudes and behaviour in their role as principal (Mpungose 2010).

The competency levels of principals are revealed in the attitude and behaviour of members of the different social groupings within the var- ious schools (Soudien 2004). The assumption in this paper is that contradictory interpretations of new legislation on principal selection and appointment may be the result of past governance traditions and expectations. The argument is whether or not aspirant principals meet appointment criteria and have the necessary leadership skills to lead and manage schools. Appointed principals should have leadership and management skills to improve performance but, according to Mattson and Harley (2002), appointment processes in South African schools usually tend to ignore the local ideals of social justice and democracy. Policy realities and stipulations for procedures and processes do not influence reform ideals and school realities (Moloi 2007). Therefore, the diverse and complex ways of leading and managing schools in South Africa result in some schools being successful whereas others fail. Leaders need to depend on others to accomplish the group's purpose and they should encourage the development of leadership across the organisation (Yukl 2009).

\section{School Leadership and Management}

The concepts of leadership, management and principalship are used interchangeably in the South African school context while the relevant literature shows that they are different (Bush 2008; Christie and Lingard 2001; Leithwood et 
al. 2002; Jossey-Bass 2000). Leaders influence goal attainment while managers attain goals through structures and processes put in place in the organisation. Leadership requires a competency to influence - and should result in - the achievement of goals entrenched in the vision and values of the school; a lack of competency may result in mediocrity and failure (Christie and Limerick 2004). Good management is essential for the successful functioning of schools (Fleisch and Christie 2004; Roberts and Roach 2006; Taylor 2007). Principalship (a management task), on the other hand, requires responsibility and accountability and it should not be achieved through shallow or immoral means.

South Africa's history of inequality has resulted in School Governing Bodies (SGBs) experiencing challenges in ensuring that the new principles, criteria and procedures for the selection and recommendation of principal appointments are properly implemented because the social realities of each SGB are different (Moses 2002: 4). The reality in schools is that the outcomes of appointment policies seldom match individual expectations or promote major group advancement (Gilmour 2001) and may lead to tension and conflict (Sayed 2002). SGBs are responsible for the selection, interviewing and recommendation of staff for appointment at the schools they govern on behalf of the State (Sayed 2002). Therefore, candidates who qualify and satisfy the criteria should be considered for appointment (Christiano 2004; Marmor 2005) because appointing a competent person may help improve the way the school operates (DoE 2005; Nieto 2005; Grieves and Hanafin 2005: 24). However, Fullan (1993) argues that appointments in an institution cannot simply be taken as proof of competence but that is sues, such as history, culture and community, should also be considered.

\section{Appointment Process and Procedure}

The "effective appointment of principals should influence school outcomes such as student achievement, attainment of the school's vision and goals, effective allocation of resources and the development of organizational structures that support instruction and learning" (Horng et al. 2009). According to Darling-Hammond et al. (2007), a nation's schools and children can only succeed if leadership is effective. Although this has been said in terms of an Amer- ican experience, the same applies to South Africa. It is also important that the way in which principals are appointed should be sensitive to past experience (Jaruzel 2004) because education functions in the context of the political, cultural and social inequities of society (Rushing 2001: 32; Jaruzel 2004) and, hence, the consequences of interventions aimed at redress might be either positive or negative (World Development Report 2004) or they may justify and perpetuate inequality instead of contributing to transformation (Mampane 2009).

Appointment to principalship is regarded as just another job which - even though it is a senior management one - could be executed by any educator who excels in teaching (Maile 2000: 379; Salazar 2007). The only requirement is a Relevant Equivalent Qualification Value (REQV) 14 , that is matric plus a teaching certificate/diploma, which is the lowest qualification that most teachers possess. Bush and Jackson observe that "training in many countries is not a requirement for appointment as a principal because there is still an (often unwritten) assumption that good teachers can become effective managers and leaders without specific preparation" (Salazar 2007) and, therefore, principals are often appointed on the basis of their successful record as teachers. The picture is similar in many European countries, including Belarus, Cyprus, and Denmark (Watson 2003). Good teaching abilities are not, necessarily, an indication that the person who is appointed will be a capable educational manager; hence, the education reform policies for Educational Leadership and Management (ELM). Kunene and Prew (2005: 4), suggest a standardised qualification for school principals, including a uniform professional and academic qualification and a career pathway for school principals.

According to Bush and Oduro (2006), the South African stipulated criterion for promotion to principalship is low and there is no provision for a 'traditional apprenticeship' before appointment - unlike Canada (Dalgleish 2009). It is, therefore, possible that this may result in unfair appointments. Although the Educators' Employment Act, 76 of 1998 (South Africa 1998) is clear concerning promotion from one level to the next, that is from a low post level (PL) to a higher one, such as PL2 then to PL3 and PL4, this is not always the case because some candidates are appointed as principals from the lowest levels 
(PL 1 or 2 ) due to internal and external influences. This practice of 'level hopping' is also apparent in Canadian education (Dalgleish 2009). Candidates who are appointed to principalships should possess leadership and management skills; however, the South African school leadership and management programme designed for principals is adapted from western countries, such as the UK, US and Australia (Christie 2010) which does not always consider the reality of previously disadvantaged communities (Bhatt et al. 1988: 150; Mattson and Harley 2002).

\section{Conceptual Framework}

The conceptual framework of the study on which this paper is based is a legislative/governance one. The focus of policy analysis and amendments to the South African Schools' Act, regarding the selection and appointment of teachers, has implications for school governance. More specifically, policy is aimed at determining the quality of procedures and processes of principal appointments in schools (Marmor 2005) which should provide an appropriate balance between all contesting candidates. The principles of equity and diversity, therefore, require that the interests of persons who have lived their lives in parts of the society - which may be different from one's own - should be compared and weighed (Marmor 2005). Equity and representivity, however, are often not easy to achieve because individuals are usually cognitively biased towards their interests and 'as a consequence controversy over the principle of equity and diversity' often result in conflict (Mampane 2009). Failure to consider the common good of a particular person may, therefore, imply that the person concerned ignores his/her own distinct interests (Marmor 2005). The assumption behind the 'common good' principle is that if the procedures followed are genuinely democratic, the outcomes would not only be justifiable but also just because authority would be grounded in the decision-maker (Naidoo 2004). According to Sayed (2002), current government policies do not, necessarily, enhance greater participation and may, in fact, contradict moves towards equity. If school governing bodies disregard individual rights in a democracy, conflict may arise over competency in leadership and management.

\section{METHODOLOGY}

This paper focuses on the procedures and processes followed in the appointment of principals for school leadership and management using three main questions from the interview protocol. The aim was to explore what motivates candidates to apply for a leadership position; their experience of the appointment processes and procedures; and prior training and skills development for the principalship. A qualitative multiple case study approach was used to explore the phenomenon using in-depth semistructured interviews (Yin 2003). The rationale for choosing multiple case studies was to compare the different cases in order to have an indepth understanding of the processes and procedures used in appointing principals. This approach in the collection of data allowed for the exploration of motivation behind the decision to become a principal; the unique appointment experiences of the principals; and the prior skills development and training in preparation for a principalship. The participants were asked the following questions, which constitute interview themes:

- What motivated you to apply for a principalship?

- What is your experience of the appointment processes and procedures?

- What prior training or skills development did you have for the position of principal?

\section{Sampling}

Purposive sampling was used to select information rich cases that would be able to answer the research questions. The sample consisted of 15 male and female primary school principals - 4 male and 3 female principals from the Limpopo Province and 5 female and 3 male principals from the Mpumalanga Province - during the first semester of 2014. The criteria for sampling the participants were: appointment to principalship in a primary school of Limpopo and Mpumalanga Provinces in South Africa; a willingness to participate in the study; and ease of access to research sites (within a $100 \mathrm{~km}$ radius of Pretoria). The principals' experience varied from 2-3 years and their qualifications ranged from matric and a certificate to an honours degree. Permission to conduct the research was granted by the Limpopo and Mpumalanga De- 
partments of Education that also provided the researcher with the names and e-mail addresses of the sampled schools. The principals gave their consent to be interviewed and appointment dates were set before a series of interviews were conducted.

\section{Data Collection}

Participants received a list of questions at least one day in advance of the interviews to assist them in reviving memories of specific events in their lives. The different principals were interviewed at their various schools using semistructured interview questions. The interview sessions lasted approximately 30 minutes and consisted of open-ended semi-structured questions - as suggested by Rubin and Rubin (2005). The primary data from multiple cases was triangulated to cross-check the consistency of the findings and to provide more comprehensive and relevant information (Cole 1994). Participants were given a copy of the interview transcripts after each round of interviews for feedback. Any deletions or revisions to the transcript during member-checking gave the study more validity because the participants checked the data analysis and interpretation (Atkinson and Hammersley 1998; Glesne 1999). Peer reviewers, colleagues and project members looked for researcher bias and requested clarification on specific analytical findings.

\section{RESULTS}

\section{Results Emerging from the Study -Presented in Three Themes}

\section{Theme 1: Prior Preparation for Principalship}

Most principals were not afforded any training or opportunities to gain management experience. Others attended workshops which were not specifically tailored for the position of principal. A few principals acquired management and leadership experience through registered courses, in-service and out-of-service workshops. The following were the principals' responses:

"I tried to take any opportunity to learn on my own. I attended workshops or in-service even outside the domain of the department, even if there was nothing to learn."
One principal obtained training from the union while another principal had no formal training for the position:

"Apart from studying, the courses or workshops that I attended were from the union. I attended curriculum courses, RNCS, introduction of new subjects and all new policies and resolutions."

"I attended courses and workshops on assessment and computer literacy and a number of conferences and programmes on curriculum issues."

A few principals studied management courses and acquired a first degree while they were teaching because of their desire to play a leading role at school. For this reason, one remarked:

"I did FDE in education management, then a degree in Education Management. I did not go further because I just devoted my time to serving children."

Some principals indicated that they served in selected leadership positions when they were teachers. One principal said:

"I got leadership through induction programmes like when I was HoD. I was trained and showed how to work hand-in-glove with the human resource. My X principal empowered me."

\section{Theme 2: Implementation of the Appointment Policy}

All except two principals who were interviewed did not go through the required level transition from classroom teacher to head of department, deputy principal and then principal. Most of the principals were appointed from their position as class-teacher to that of principal.

"I moved straight from the classroom to principal. The in-between levels, I never had the opportunity to serve in them."

One of the appointed principals had a formal qualification in leadership and management acquired by enrolling for an Advance Certificate in Education (ACE). He explained:

"A qualification that I obtained helped me become a principal. It is called Advanced Certificate in Education, Leadership and Management. That is what I did on my own."

Another principal experienced some interference from external and internal parties regarding who was to be appointed to the principalship 
position in a school. According to this principal, the interests of union members and those of staff members were not, necessarily, in the best interest of the school.

"External factors cropped in when the unions tried to push for a candidate who is their member. Sometimes some of the unions may have an influence...if they are not satisfied they can block the process or they can prolong the process".

\section{Theme 3: Motivation for Applying for Principalship}

The factors that motivated aspiring principals to apply for principalships differed and were mostly a combination of intrinsic and extrinsic motivators which included personal values, knowledge, skills, and experience in leadership and management schools. One said:

"Well, I have passion of working with people. I also like exploring all avenues and one avenue that I wanted to explore at school level is to become a school principal. I was not satisfied with where I was and wanted to gain more knowledge."

Almost all the principals cited hard work, competence and experiences of certain tragic events as motivators for applying for a principalship. One participant explained:

"I was a mere CS1 educator when I was involved in an accident where a school child passed away. I got a small scratch, and when I was lying there, I asked God to save me and I also said that I will devote every second of my life for children."

Both male and female principals indicated that their reason for applying for a principalship was because they wanted to make a positive contribution to education. This is how one female principal put it:

"We have more male principals, why not females. I feel I can bring change in the education system especially in the rural areas where there is a need for good leadership."

Another principal with leadership abilities described enthusiasm for, and interest in, leading others as the main reason for applying for the position.

"I have always wanted to lead others. Unconsciously it was always there, I did not plan it. I find it challenging to take a back seat especially in areas where I can help."

\section{DISCUSSION}

Without effective leaders most of the goals for educational improvement will be difficult to achieve and, therefore, the appointment of incompetent leaders may undermine the very standards and goals we set for our schools. Public and private school principals cannot function as managers tasked with adhering to district rules; carrying out regulations; and avoiding mistakes. Principals have to be - or become leaders of learning who can develop a team that delivers effective teaching and learning (The Wallace Foundation 2012). Districts should create clear, rigorous job requirements that detail what principals must know and do and these should emerge from what research indicates as the knowledge, skills and required behaviour of principals. Researchers who have examined education leadership agree that effective principals are responsible for establishing a school-wide vision of commitment to high standards and the success of all students (Yukl 2009). Effective leaders influence the leadership and management of schools as well as the attitudes to teaching within schools. Unfair appointment procedures and processes result in the negative attitudes, resistance and non-cooperation of teachers.

\section{CONCLUSION}

The study on which this paper is based highlighted a number of shortcomings in the appointment of teachers to principalships. Teachers who are appointed to principalships do not have the same competencies. Some principals appear to be more competent than others because of differences in their length of service, management abilities and qualification levels. A major factor that emerged concerning the flawed procedures and processes was the acknowledgement by some of the principals of their inability to effectively carry out their responsibilities; the lack of prior training and the low criteria for progression to principalship resulted in poor school leadership and management.

\section{RECOMMENDATIONS}

It is recommended that there should be nonengagement of union members in the appointment procedures and processes; that neutral people should be involved; and that monitoring 
and evaluation tools should be used to ensure the quality appointments of principals. The existing criteria for appointment to the position of principal should also be revised to include higher academic and professional qualifications and training in leadership and management skills.

\section{REFERENCES}

Bush T 2008. Leadership and Management Development in Education. London: Sage Publications Ltd.

Bush T, Odura KT 2006. New principals in Africa: Preparation, induction and practice. Journal of Educational Administration, 44: 359-375.

Bush T, Moorosi P 2005. Preparing new principals in South Africa- The ACE School Leadership Programme. South African Journal of Education, 3: 31-43.

Carrim N 2003. Teacher identities: Tension between roles. In: K Lewin, M Samuel, Y Sayed (Eds.): Changing Patterns of Teacher Education in South Africa: Policy, Practice and Prospects. Sandown: Heinemann, pp. 306-322.

Christiano T 2004. Is normative rational choice theory self-defeating? Ethics, 115(1): 122-141.

Christie P 1998. Schools as (dis)organisations: The "breakdown of the culture of learning and teaching" in South African schools. Cambridge Journal of Education, 28(3): 283-300.

Christie P 2001. Improving school quality in South Africa: A study of schools that have succeeded against the odds. Journal of Education, 26: 40-65.

Christie P 2010. Landscape of leadership in South African schools: Mapping the changes. Educational Management Administration and Leadership, 38(6): 694-711.

Christie P, Lingard B 2001. Capturing Complexity in Educational Leadership. Paper Presented to the AERA Conference, Seattle, 10-14 April.

Christie P, Limerick B 2004. Leadership as a field of study. Discourse: Studies in the Cultural Politics of Education, 25(1): 3-6.

Darling-Hammond L LaPointe M Meyerson D, Orr MT, Cohen C 2007. Preparing School Leaders for a Changing World: Lessons from Exemplary Leadership Development Programs. Stanford, CA: Stanford University, Stanford Educational Leadership Institute.

Dalgleish A 2009. Pathways to Principalship. A Thesis Submitted to Auckland University of Technology in Partial Fulfilment of the Requirements for the Degree of Master of Education (MEd). School of Education. New Zealand: Auckland University of Technology.

Department of Education 2005. Draft Document: The South African Standards for Principalship: Leading and Managing South African Schools in the $21^{\text {st }}$ Century. Pretoria: Government Printers.

Department of Education 2008. Understand School Leadership and Governance in the South African Context: A Module of the Advanced Certificate: Education (School Management and Leadership). South Africa: Department of Education.
Fleisch B, Christie P 2004. Structural change, leadership and school effectiveness/improvement: Perspectives from South Africa. Discourse, 25(1): 95111.

Fullan M 1993. Change Forces: Probing the Depths of Educational Reform. London: The Falmer Press.

Fullan M 2000. The three stories of education reform. Phi Delta Kappan, 81(8): 581-590.

Fullan M 2007. The New Meaning of Educational Change. $4^{\text {th }}$ Edition. New York: Teachers College Press.

Gilmour JD 2001. Intensions or in tension? Recent education reforms in South Africa. International Journal of Educational Development, 21(1): 5-19.

Glesne C, Peshkin A 1992. Becoming Qualitative Researchers: An Introduction. New York: Longman.

Grieves J, Hanafin P 2005. Human resource management: The Achilles heel of school governance. Employee Relations Journal, 27(1): 20- 46.

Hammersley-Fletcher L, Kirkham G 2007. Middle leadership in primary school communities of practice: Distribution or deception. School Leadership and Management, 27(5): 423-435.

Horng EL, Kalogrides D, Loeb S 2009. Principal Preferences and the Unequal Distribution of Principals Across Schools. Calder Working Paper 36. Washington, DC: The Urban Institute.

Jaruzel M 2004. South Africa reflects on 10 years of democracy. Matt Mosaic, 3(2): 2-12.

Johnson RW 2004. South Africa: The First Man, The Last Man. Cape Town: Jonathan Lingard 2001 Ball Publishers.

Jossey B 2000. The Jossey-Bass Reader on Educational Leadership. San Francisco: Jossey-Bass.

Kunene Z, Prew M 2005. South African Qualification for Principals: Reality or dream? Paper presented at the $7^{\text {th }}$ World Convention of the International Confederation of Principals. Cape Town, 12 July 2005.

Kvale S, Brinkmann S 2009. Interviews-learning the Craft of Qualitative Research Interview. $2^{\text {nd }}$ Edition. Beverly Hills, California: Sage Publications.

Leithwood K, Steinbach R, Jantzi D 2002. School leadership and teachers' motivation to implement accountability policies. Educational Administration Quarterly, 38(1): 94-119.

Leithwood KA, Riehl C 2003. What Do We Already Know About Successful School Leadership? Chicago: American Educational Research Association (AERA).

Leithwood K, Louis KS, Anderson S, Wahlstrom, K 2004. How Leadership Influences Student Learning. Minessota: Center for Applied Research and Educational Improvement.

Leithwood K, Day C, Sammons HP, Hopkins D 2006. Seven Strong Claims about Successful School Leadership. Nottingham, England: National College of School Leadership.

Loeb S, Kalogrides D, Horng E 2010. Principal preferences and the unequal distribution of principals across schools. Education Evaluation and Policy Analysis, 32: 205-229.

MacBeath J, Gray J, Cullen J, Frost D, Steward S, Swaffield S 2007. Schools on the Edge: Responding to Challenging Circumstances. London: Paul Chapman Publishing. 
MacBeath J, Mortimore P (Eds.) 2001. Improving School Effectiveness. Buckingham, Philadelphia: Open University Press.

Maile S 2012. The Making of South African School Principals: An Empirical Perspective. Singapore: International Conference on Education and Management Innovation (IPEDR).

Mampane Sharon Thabo 2009. How School Governing Bodies Understand, Negotiate and Implement Changes in Government Legislation with Respect to the Appointment of Teachers. PhD Thesis, Unpublished. Pretoria: University of Pretoria.

Marmor A 2005. Authority, equality and democracy. The School of Law and the School of Philosophy, 18(3): 315-345.

Mattson E, Harley K 2002. Teacher identities and strategic mimicry in the policy/ practice gap. In: K Lewin, M Samuel, Y Sayed (Eds.): Changing Patterns of Teacher Education in South Africa. Cape Town: Heinemann, P. 388.

Miller MA 2008. A Study of the Career Paths and Leadership of Male Principals in the Elementary Schools of Ohio. PhD Dissertation. Ohio: Graduate College of Bowling Green State University.

Mitgang L 2010. Flipping the script. The School Administrator, 11(67): 15-18.

Moloi K 2007. An overview of education management in South Africa. South African Journal of Education, 27(3): 463-476.

Moses MS 2002. Embracing Race: Why We Need Raceconscious Education Policy. New York: Teacher's College, Columbia University.

Mpungose J 2010. Constructing principals' professional identities through life stories: An exploration. South African Journal of Education, 30: 527-537.

Naidoo JP 2004. Educational Decentralisation and School Governance in South Africa: From Policy to Practice. PhD Thesis. USA: Harvard Graduate School of Education.

Naidoo JP 2005. Educational Decentralisation and School Governance in South Africa: From Policy to Practice. Paris: International Institute for Educational Planning.

Nieto S 2005. Public education in the twentieth century and beyond: High hopes, broken promises, and an uncertain future. Harvard Educational Review, 75(1): 1 .

Palomares LB, Castillo JLA 2004. Professionalising the principalship in Spain: Barriers in teachers' minds? International journal of Leadership in Education, (7): 147-163.

Prew M 2007. Successful principals: Why some principals succeed and others struggle when faced with innovation and transformation. South African Journal of Education, 27(3): 447-462.
Republic of South Africa 1996. The South African Schools Act. Government Gazette, Vol. 377(17579), Act No. 84 of 1996. Cape Town: Government Printers.

Republic of South Africa 1998. The Employment of Educators Act (EEA), Act 76 of 1998. Pretoria: Government Printers.

Republic of South Africa 2000. Promotion of Equality and Prevention of Unfair Discrimination 2000- Act No. 4 of 2000. Pretoria: Government Printers.

Republic of South Africa 2005. The Education Laws Amendment Act (ELAA)- Act 24 of 2005. Pretoria: Government Printers.

Roberts J, Roach J 2006. Leadership Styles and Practices in Effective Schools. Johannesburg: Matthew Goniwe School of Leadership and Management.

Rubin HJ, Rubin I 2005. Qualitative Interviewing: The Art of Hearing Data. $2^{\text {nd }}$ Edition. Thousand Oaks, California: Sage Publication.

Rushing W 2001. Inequality and education reform formulating a macro-historical sociology perspective. Race Ethnicity and Education, 4(1): 29-44.

Salazar PS 2007. The professional development needs of rural high school principals: A seven-state study. The Rural Educator, 28(3): 8.

Sayed Y 2002. Democratising education in a decentralised system: South African policy practice. Compare, 32(1): 35-46.

Soudien C 2004. Change in Post-apartheid South Africa. South Africa: HSRC Publishers.co.za.

Taylor N 2006. Schools, Skills and Citizenship. JET Bulletin No. 15, Focus on Challenges across the Education Spectrum. Johannesburg: Joint Education Trust.

Taylor N 2007. Equity, efficiency and the development of South African schools. In: T Townsend (Ed.): International Handbook of School Effectiveness and Improvement. Dordrecht: Springer, pp. 523-540.

The Wallace Foundation 2012. The School Principal as Leader: Guiding Schools to Better Teaching and Learning. Seattle, Washington: James Harvey \& Associates.

Van der Westhuizen P, Van Vuuren H 2007. Professionalising principalship in South Africa. South Africa Journal of Education, 27(3): 431-445.

World Development Report 2004. Making Services Work for Poor People. Washington, DC: Development Economics Vice Presidency.

Yin RK 2003. Case Study Research: Design and Methods. $3^{\text {rd }}$ Edition Thousand Oaks, CA: Sage Publications.

Yukl G 2006. Leadership in Organisations. $6^{\text {th }}$ Edition. Upper Saddle River NJ: Pearson-Prentice Hall.

Yukl G 2009. Leadership in Organizations. Upper Saddle River NJ: Pearson-Prentice-Hall. 